\title{
Histologic and Histomorphometry of Uterine of Gayo Mare
}

\author{
Juli Melia ${ }^{*}$, Welda R. Brillian ${ }^{2}$, Erdiansyah Rahmi ${ }^{1}$, Rosmaidar Rosmaidar ${ }^{1}$, \\ Hafizuddin Hafizuddin ${ }^{1}$, Amrozi Amrozi ${ }^{3}$ \\ ${ }^{I}$ Faculty of Veterinary Medicine Universitas Syiah Kuala, Banda Aceh, Indonesia \\ ${ }^{2}$ Veterinarian Study Program Faculty of Veterinary Medicine Universitas Syiah Kuala, Banda Aceh, Indonesia \\ ${ }^{3}$ Faculty of Veterinary Medicine IPB University, Bogor, Indonesia \\ *Corresponding author. Email: julimelia@unsyiah.ac.id
}

\begin{abstract}
This study was aimed at finding out the histology description and histomorphometry of uterine Gayo mare. The samples were collected from three Gayo mares in Takengon, Central Aceh. The uterine samples were processed by microtechnique and stained with hematoxylin-eosin before examined under a binocular microscope. The results showed that the histological description of Gayo mare uterine was composed of three layers: the endometrium, myometrium, and perimetrium. The endometrium was composed of epithelium simple columnar cell, lamina propria, and uterine glands. The myometrium was composed of longitudinal and circular muscle fiber and blood vessels. Perimetrium was the most outer layer of the uterine consisting of connective tissue. The uterine cervix consists of the primary, secondary, and tertiary fold. The endometrial layer thickness of corpus uteri was $1202.43 \pm 120.1 \mu \mathrm{m}$, and uterine cornua $1218.52 \pm 82.5 \mu \mathrm{m}$. The myometrial thickness of corpus uteri was $4468.94 \pm 165.9 \mu \mathrm{m}$, and uterine cornua $4200.07 \pm 174.7 \mu \mathrm{m}$. The perimetrium thickness of corpus uteri and uterine cornua were $119.70 \pm 8.1 \mu \mathrm{m}$ $99.73 \pm 18.6 \mu \mathrm{m}$, respectively. It can be concluded that the uterine layer has the same layer; however, the uterine gland is only found in the endometrial layer of the uterine corpus and uterine cornua. The myometrium and perimetrium layers are thicker in the uterine corpus, while the endometrium layer was thicker in the uterine cornua.
\end{abstract}

Keywords: Gayo mare, Histology, Uterine

\section{INTRODUCTION}

Gayo mare is a type of mare native to Indonesia. Currently, the Gayo mare population has decreased, probably due to the crossbreeding of the Gayo mare with other mares, the increased demand for mare meat for consumption and the shift in the use of marepower with modern equipment [1]. To prevent the extinction of Gayo mare, it is necessary to increase the Gayo mare population, specifically the reproduction. According to Blakely and Bade [2], reproductive problems often occur in mare are failure to detect estrous and abnormal reproductive tracts.

The female Gayo mare's reproductive organs consist of the ovaries, oviduct, uterus (cornua, corpus and cervix), vagina, and vulva [3]. The mare's uterus is a Y-shaped muscular organ consisting of the cervix, corpus, and a pair of uterine cornua $[3,4]$. In general, the uterus consists of a perimetrial layer, myometrial layer and endometrial layer. The uterus is a part of the reproductive organs that plays a vital role for a successful pregnancy. If there is a problem with the uterus, it will lead to the failure of mare reproduction. The problems that often occur in the equine uterus include Contagious Equine Metritis (CEM) [5], uterine cysts [6], uterine tumours [7], endometriosis, pyometra and endometritis [8].

There are very few histological studies regarding the morphology and characteristics of the uterus. Therefore, this research was carried out to obtain basic data on the normal histological picture of the reproductive organs, especially the uterus, as a reference for handling various reproductive problems to increase the Gayo mare population. This study aims to determine the histological and histomorphometry features of Gayo mare's uterus. This study is expected 
to provide preliminary data information regarding the histological features of the uterus in Gayo mares as well as a basis for diagnosing histopathological reproductive disorders and as a reference for further studies.

\section{MATERIALS AND RESEARCH METHODS}

\subsection{Collection of the uterus samples}

Uterine samples were collected from 3 Gayo mares in Takengon, Aceh Tengah. The uterus is cleaned with a physiological $0.9 \% \mathrm{NaCl}$ solution until clean. The uterus is extracted in three different parts, namely the cornua, corpus, cervix. Sample preparation was done by cutting $2 \mathrm{~cm}$ each of the cornua, corpus, and cervical tissue and then put it in a $10 \%$ NBF fixative. Each sample is labeled and then transferred to a $70 \%$ alcohol solution as a stopping point until the dehydration process is carried out.

\subsection{Histological Preparation}

The histological preparations of Gayo mare's uterus refer to Kiernan [9]. The process begins with tissue dehydration using a serial concentration of alcohol solution $(80 \%, 90 \%, 95 \%$, absolute I and absolute II), purification with xylene solution, and tissue infiltration in paraffin three times and continued with embedding in liquid paraffin to form a paraffin block. The tissue block is sliced using a microtome with a thickness of 5 $\mu \mathrm{m}$. The slices were placed on a tissue bath, mounted on a glass object and incubated on a slide warmer.

\subsection{Hematoxylin-Eosin Staining}

The staining begins with the deparaffinization process using xylene I for 5 minutes and xylene II for 2 minutes. Then proceed with the rehydration process with decreased serial concentration of alcohol from absolute alcohol I and II, 96\% alcohol I and II, alcohol $90 \%$ each for 2 minutes, then the tissue slides are rinsed with running water. The next process is to immerse the tissue slides in the hematoxylin solution for 5 minutes, then rinse the tissue slides with running water. After that, the tissue slides were inserted into the eosin solution for 5 minutes. The dehydration process was then carried out again with $96 \%$ alcohol I and II, absolute I and II, each two times immersed. After that, the clearing process was carried out with xylene I, II, and III for 3 minutes each, then mounting with Entellan® [9]. Observations were made with a light microscope (Olympus CX31) and followed by taking photos using a Sigma ${ }^{\circledR}$ microscope camera, and microscopic measurements using the toupview application.

\subsection{Uterine Histomorphometry Measurement}

Observation and histomorphometry measurements of the Gayo mare's uterus were carried out by measuring the uterine layer using a microscope with the help of toupview software. The parts measured were the thickness of the perimetrium, myometrium, and endometrium.

\subsection{Data Analysis}

The data obtained from this study's results were analyzed descriptively and presented in the form of histological images and tabulated in the form of mean \pm standard deviation (SD).

\section{RESULTS AND DISCUSSION}

The result of microscopic observation shows that the histological structure of Gayo mare's uterus is composed of three layers: endometrium, myometrium and perimetrium. The endometrial layer consists of epithelial cells, lamina propria and uterine glands; the myometrium consists of muscle fibers and blood vessels; and the perimetrium consists of connective tissue.

\subsection{Cervical Uteri}

The results showed that the uterine cervix of the Gayo mare was composed of endometrium, myometrium and perimetrium which has longitudinal folds consisting of primary, secondary, and tertiary folds, and thick muscle layers. This study's results are the same as those reported by Senger [10], which state that these folds and layers differentiate the mare cervix's structure from the ring-shaped cow's cervix structure. The histology of the uterine cervix of Gayo mares is presented in Figure 1. Bacha and Bacha [11] stated that a layer of cylindrical epithelial cells was also found in the cervix, which might be ciliated cells. Similar findings were also found in the Gayo mare cervix (Figure 1C). These cilia cells play a role in directing spermatozoa to the fertilization site [12].

\subsection{Uterine corpus}

The uterine corpus is a cylindrical structure that connects the uterine cornua to the cervix [13]. Microscopically, the Gayo mare's uterine corpus is composed of three layers, namely: endometrium, myometrium and perimetrium. The layer of the endometrium consists of epithelial cells, lamina propria and uterine glands. Epithelial cells found on the endometrium's surface are single cylindrical epithelium formed by secretory and ciliated cells. In the lamina propria, there are many uterine glands. According to 
Bacha and Bacha [11], the uterine glands are characterized by a circular shape in mares.
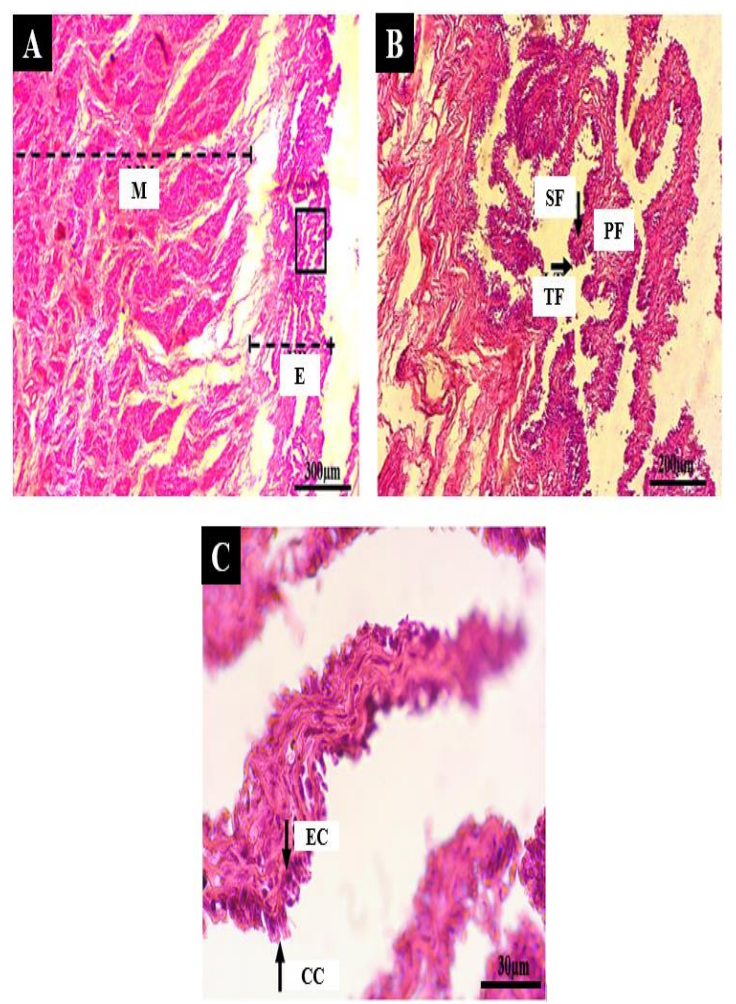

Figure 1. Histology of the cervix of the Gayo mare. A) The layer of the cervix, B) Insert pictures A, C) Epithelial cells found in the cervix uteri. (E: Endometrium, M: Myometrium, PF: Primary Fold, SF: Secondary Fold, TF: Tertiary Fold, EC: Epithelial Cell, CC: Cilia Cell). Hematoxylin-eosin staining.

The results showed that the Gayo mare's uterine corpus had a thicker layer than the uterine cornua. The uterine glands are predominantly found in the corpus uteri rather than the uterine cornua. Similar findings were also reported by Sahu et al. [14] in Kendrapada sheep. According to Abd-Elnaeim [15] the ciliated surface of the mare's endometrium is bushy or clustered. Equine endometrial secretory cells produce, store, and secrete oxytocin and are most likely involved in stimulating and maintaining uterine contractility. After estrous, the number of secretory endometrial cells decreases rapidly and only a few are present during the luteal phase. The number of ciliated cells increases and reaches a maximum in mid-diestrus but again decreases towards the end of the luteal phase [16].

The layer of the myometrium consists of longitudinal muscle fibers, blood vessels and circular muscle fibers. Blood vessels function to provide blood to the endometrium. During pregnancy, the muscle fibers increase in size and thickness [17]. The last layer is the perimetrium, the uterine corpus's outermost layer, which consists of loose connective tissues. The histology of the uterine corpus of the Gayo mare is presented in Figure 2.

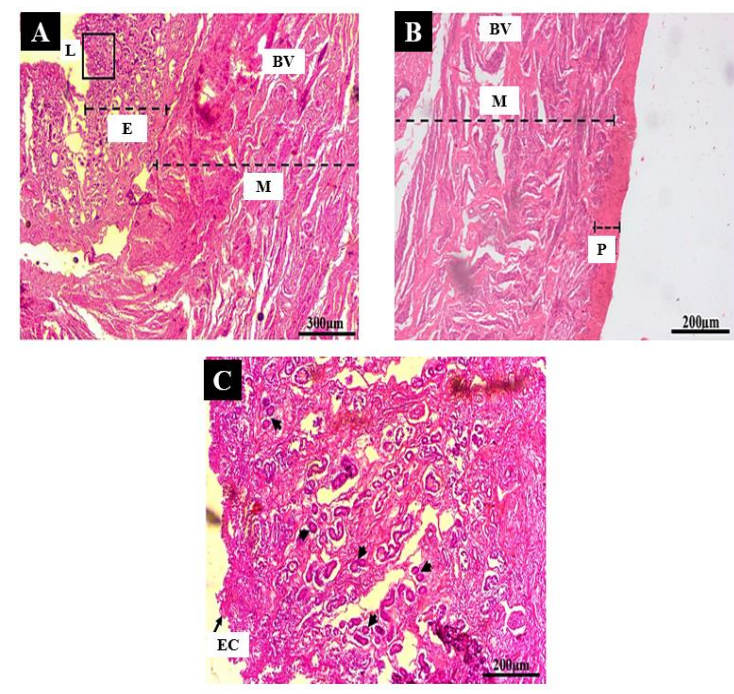

Figure 2. Histological picture of the uterine corpus of the Gayo mare. A and B) The layers of the uterine corpus, C) Insert image A. (L: lumen, E: Endometrium, M: Myometrium, P: Perimetrium, BV: Blood Vessels, EC: Epithelial Cell, Arrowhead: uterine glands that fill the layer) endometrium corpus uteri). Hematoxylin-eosin staining.

\subsection{Uterine Cornua}

Microscopically, there is no difference between the uterine cornua of the Gayo mare and the uterine corpus. The uterine cornua of the Gayo mare is composed of three layers: endometrium, myometrium and perimetrium. The layer of the endometrium consists of epithelial cells, lamina propria and uterine glands. The epithelial cells found on the surface of the endometrium are in the form of cylindrical epithelium. Melia et al. [3], stated that during estrous, the endometrium experiences thickening due to estrous mucus production in the endometrium.

Many uterine glands were also found in the uterine cornua of the Gayo mare. The uterine gland or uterine milk contains many proteins which are essential for the survival, growth, and development of the embryo in the early stages of pregnancy [18]. Older mares often show decreased ability to produce healthy foals because of degenerative changes in the endometrium called endometriosis that affects the number and morphology of the endometrial glands [19].

At about 36-150 days of gestation, an endometrial cup is formed as a source of Equine Chorionic Gonadotrophin (ECG), previously known as the Pregnant Mare Serum Gonadotropin (PMSG). ECG plays a role in follicular development and the 
production of estrogen and progesterone [20]. In pregnant mares, progesterone plays a role in uterine gland adenogenesis or uterine gland development [21].

Myometrium of Gayo mare's uterine cornua consists of longitudinal muscle fibers, blood vessels and circular muscle fibres. In this layer, many blood vessels provide blood to the endometrium. The last layer is the perimetrium, the outermost layer of the Gayo mare's uterine cornua which consists of loose connective tissue. The histology of the uterine cornua of the Gayo mare is presented in Figure 3.
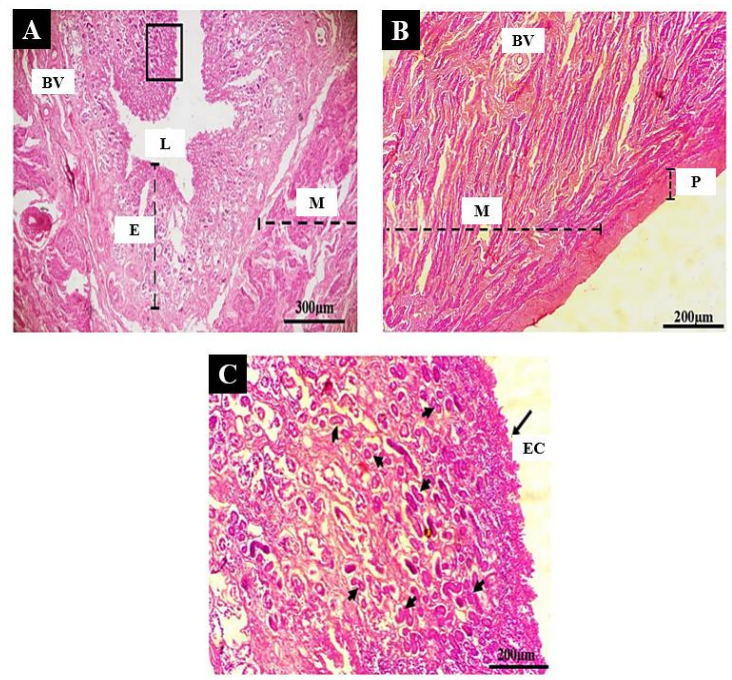

Figure 3. Histology of the Gayo mare's uterine cornua. A and B) The layers of the uterine cornua, C) Insert image A. (L: lumen, E: Endometrium, M: Myometrium, P: Perimetrium, BV: Blood Vessels, EC: Epithelial Cells, Arrow sign: uterine glands that fill the layer) uterine endometrium). Hematoxylin-eosin staining.

\subsection{Histomorphometry of Gayo mare's uterine}

All histologic samples of Gayo mare's uterine were measured for each layer's thickness, including the perimetrium, myometrium and endometrium. Uterine measurements can only be performed on the uterine cornua and uterine corpus, while the uterine cervix cannot be measured. The measurements are presented in Table 1.

The results showed that the thickest layer of Gayo mare's endometrium was in the uterine cornua, namely $1218.52 \pm 82.5 \mu \mathrm{m}$. This size was thicker than the endometrium thickness of fertile Acehnese cattle $(187.39 \pm 29.09 \mu \mathrm{m})[22]$ and also that of multiparous local goats $(960.63 \pm 8.00 \mu \mathrm{m})$ [23]. Melia [1] stated that the thickness of the endometrium increases when the mare is estrous.

The most significant myometrial thickness of Gayo mare was found in the uterine corpus, namely 4468.94 $\pm 165.9 \mu \mathrm{m}$. This size is larger than that of multiparous bean goat myometrium $(550.36 \pm 14.3 \mu \mathrm{m})$ [23] and also larger than that of fertile Acehnese cattle (277.91 \pm $42.88 \mu \mathrm{m})$ [22]; and in kendrapada sheep $(307,881 \pm$ $24.67 \mu \mathrm{m})$. This study showed an increase in the thickness of the myometrial layer.

The most significant thickness of Gayo mare perimetrium was in the uterine corpus: $119.70 \pm$ $8.13 \mu \mathrm{m}$. This size is larger than the perimetrial thickness of Kendrapada sheep $(22,251 \pm 3.52 \mu \mathrm{m})$ [14] and greater than that of multiparous local goats $(30.66$ $\pm 1.67 \mu \mathrm{m})[23]$.

Table 1. The thickness of Gayo mare's uterine layer, enlarged 4 times

\begin{tabular}{|l|l|l|}
\hline \multirow{2}{*}{ Layer } & Uterine & Corpus $(\mu \mathrm{m})$ \\
\cline { 2 - 3 } & Cornua $(\mu \mathrm{m})$ & $1202.43 \pm 120.1$ \\
\hline Endometrium & $1218.52 \pm 82.5$ & $4468.94 \pm 165.9$ \\
\hline Myometrium & $4200.07 \pm 174.4$ & $119.70 \pm 8.1$ \\
\hline Perimetrium & $99.73 \pm 18.6$ & \\
\hline
\end{tabular}

Morphometrically, the lengths of the uterine cornua and corpus of foreign mares was $25 \mathrm{~cm}$ and $18-20 \mathrm{~cm}$, respectively [4] which were longer than that reported by Melia et al. [3] $(21.00 \pm 0.47 \mathrm{~cm}$ and $17.50 \pm 0.50 \mathrm{~cm}$, respectively). The cervical length of Gayo mares is $6.50 \pm 0.50 \mathrm{~cm}$ [3] smaller than the cervix of foreign mares, which is $6-8 \mathrm{~cm}$ [4]. The difference in histological structure observed in this study is in accordance with the function of each part of the uterus as a site for spermatozoa capacitation, embryo/fetal implantation, placental junction, and fetal development. The conclusion of the studies showing that the uterine layer consists of the endometrium, myometrium, and perimetrium. In the uterine cervix, there are primary, secondary, and tertiary folds. While the uterine glands are only found 
in the endometrium layer of the uterine corpus and cornua. Myometrium and perimetrium of the Gayo mare are thicker in the uterine corpus, while the thick layer of the endometrium of the Gayo mare is found in the uterine cornua.

\section{CONCLUSION}

The uterine layers of Gayo Mares have the same layers; but, the uterine gland is only found in the endometrial layer of the uterine corpus and uterine cornua. The myometrium and perimetrium layers are thicker in the uterine corpus, while the endometrium layer was thicker in the uterine cornua.

\section{AUTHORS’ CONTRIBUTIONS}

All authors contribute equally to this study.

\section{ACKNOWLEDGMENT}

The author thanked all members of this research team as well as all parties that involved in this study.

\section{REFERENCES}

[1] J. Melia, Studi Fisiologi Reproduksi Kuda Gayo Sebagai Upaya Penyelamatan Plasma Nutfah Kuda Asli Indonesia, in, IPB University, Bogor, 2017.

[2] J. Blakely, D. Bade, Ilmu Peternakan, 4 ${ }^{\text {th }}$ Alih Bahasa: Srigandono, B. dan Soedarsono (Judul Asli The Science Of Animal Hubandry, Gadjah Mada University Press, Yogyakarta, 1995.

[3] J. Melia, M. Agil, I. Supriatna, A. Amrozi, Anatomi dan gambaran ultrasound organ reproduksi selama siklus estrus pada kuda gayo betina J. Kedokt. Hewan. 10(2) (2016) 103-108. DOI:https://doi.org/10.21157/j.ked.hewan.v10i2. 5026

[4] C. Davies-Morel, Equine reproductive physiology, Breeding and study management, 2nd, Farming Press, Ipswich, UK, 2008.

[5] M.L. Schulman, C.E. May, B. Keys, A.J. Guthrie, Contagious equine metritis: artificial reproduction changes the epidemiologic paradigm, Vet. Microbiol. 167(1-2) (2013) 2-8.

[6] A. Carluccio, A. Gloria, F. Mariotti, L. Petrizzi, V. Varasano, D. Robbe, A. Contri, Ethanol sclerotherapy for the treatment of uterine cysts in the mare, J. Equine Vet. Sci. 63 (2018) 27-29.

[7] M. Quartuccio, S. Cristarella, M. La Spisa, F. Marino, A. Ieni, L. Licata, G. Lanteri, Multiple uterine subserosal and submucosal intramural leiomyomas in a mare: an immunohistochemical study, J. Equine Vet. Sci. 35(4) (2015) 332-336.

[8] P.M. McCue, The problem mare: management philosophy, diagnostic procedures, and therapeutic options, J. Equine Vet. Sci. 28(11) (2008) 619-626.

[9] J. Kiernan, Histological and histochemical methods: Theory and practice, $5^{\text {th }}$ ed., Scion Publishing Limited, Banbury, UK, 2015.

[10] P.L. Senger, Pathways to pregnancy and parturition. $2^{\text {nd }}$ Rev Ed., Washington State University Research \& Technology Park, Pullman (USA), 2005.

[11] W.J. Bacha, L.M. Bacha, Color Atlas of Veterinary Histology, John Wiley \& Sons, 2012.

[12] K. Mullins, R. Saacke, Study of the functional anatomy of bovine cervical mucosa with special reference to mucus secretion and sperm transport, Anat. Rec. 225(2) (1989) 106-117.

[13] S. Jayachitra, Comparison of Uterus in Heifer and she buffalo by corrosion cast technique, J. Pharmacog. Phytochem. 1(1) (2018) 2897-2898.

[14] S. Sahu, R. Das, S. Sathpathy, U. Mishra, S. Dash, Gross, histological and histochemical studies on the uterus of Kendrapara sheep (Ovaries) at different age groups, J. Entomol. Zool. Stud. 5(6) (2017) 2337-2342.

[15] M.M. Abd-Elnaeim, Morphological characteristics of the donkey (Equus asinus) uterus during estrus: light, scanning and transmission electron microscopic study, J. Agric. Vet. Sci. 1 (2008) 47-57.

[16] C. Aurich, Reproductive cycles of horses, Anim. Reprod. Sci. 124(3-4) (2011) 220-228.

[17] N.L.E. Setiasih, P. Suastika, L.G.S.S. Heryani, N.N.W. Susari, Struktur histologi uterus anjing kintamani pada periode dewasa kelamin, Buletin Veteriner Udayana. 11(1) 39-43. DOI:10.24843/bulvet.2019.v11.i01.p07

[18] M. Hanada, Y. Maeda, M.-A. Oikawa, Equine endometrial gland density and endometrial thickness vary among sampling sites in thoroughbred mares, J. Equine Sci.. 23(3) (2012) 35-40. DOI:https://doi.org/10.1294/jes.23.35

[19] C.A. Gray, F.F. Bartol, B.J. Tarleton, A.A. Wiley, G.A. Johnson, F.W. Bazer, T.E. Spencer, Developmental biology of uterine glands, Biol. Reprod. 65(5) (2001) 1311-1323.

[20] A. Koets, The equine endometrial cup reaction: A review, Vet. Quarterly. 17(1) (1995) 21-29. 
[21] S. Wilsher, A.C. Lefranc, W. Allen, Post natal oestrogen administration stimulates precocious endometrial gland development in the horse, Equine. Vet. J. 41(7) (2009) 678-684.

[22] C.N. Thasmi, T.N. Siregar, S. Wahyuni, D. Aliza, B. Panjaitan, N. Nazaruddin, F.N. Sabila, M. Fallatanza, Anatomical and histological changes of uterine horn of Aceh cattle with repeat breeding, J. Adv. Vet. Anim. Res. 5(4) (2018) 445 .

[23] A.S. Qureshi, M. Mohsin, S. Rehan, Effect of parity on gross and microscopic structure of uterus in teddy goats (Capra hircus), Ruminant Science. 4(2). 